\title{
НОВОЕ ГИДРАТЦЕЛЛЮЛОЗНОЕ ВОЛОКНО ИЗ ЛЬНЯНОЙ ЦЕЛЛЮЛОЗЫ
}

\author{
И. С. Макаров, Л. К. Голова, М.И. Виноградов, Ю.А. Егоров, \\ В. Г. Куличихин, Ю.М. Михайлов
}

\begin{abstract}
ИГОРЬ СЕРГЕЕВИЧ МАКАРОВ - к.х.н., с.н.с., Федеральное государственное бюджетное учреждение науки Ордена Трудового Красного Знамени Институт нефтехимического синтеза им. А.В. Топчиева РАН, лаборатория № 11 «еология полимеров».E-mail: makarov@ips.ac.ru.
\end{abstract}

ЛЮДМИЛА КОНСТАНТИНОВНА ГОЛОВА - к.х.н., в.н.с., Федеральное государственное бюджетное учреждение науки Ордена Трудового Красного Знамени Институт нефтехимического синтеза им. А.В. Топчиева РАН, лаборатория № 11 «Реология полимеров».

МАРКЕЛ ИГОРЕВИЧ ВИНОГРАДОВ - к.х.н., м.н.с., Федеральное государственное бюджетное учреждение науки Ордена Трудового Красного Знамени Институт нефтехимического синтеза им. А.В. Топчиева РАН, лаборатория № 11 «Реология полимеров».

ЮРИЙ АНАТОЛЬЕВИЧ ЕГОРОВ - к.х.н., н.с., Федеральное государственное бюджетное учреждение науки Ордена Трудового Красного Знамени Институт нефтехимического синтеза им. А.В. Топчиева РАН, лаборатория № 11 «Реология полимеров».

ВАЛЕРИЙ ГРИГОРЬЕВИЧ КУЛИЧИХИН - д.х.н., чл.-корреспондент РАН, профессор, заведующий лаборатории, Федеральное государственное бюджетное учреждение науки Ордена Трудового Красного Знамени Институт нефтехимического синтеза им. А.В. Топчиева РАН, лаборатория № 11 «Реология полимеров».

ЮРИЙ МИХАЙЛОВИЧ МИХАЙЛОВ - д.х.н., академик РАН, Федеральное государственное бюджетное учреждение науки Федеральный исследовательский иентр химической физики им. Н.Н. Семенова Российской академии наук.

119991, ГСП-1, Москва, Ленинский проспект, 29, Институт нефтехимического синтеза им. А.В. Топчиева.

Разработан метод получения новых гидратиеллюлозных волокон из растворов льняной целлюлозы в $N$-метилморфолин-N-оксиде с использованием твердофазного способа активачии целлюлозы растворителем. Исследована растворимость льняной целлюлозы в данном растворителе, проведен сравнительный анализ реологического поведения растворов льняной и древесной целлюлозы и определены оптимальные температурно-концентрачионные условия получения гидратиеллюлозных волокон. Исследование структуры методами РСА и ИК-Фурье спектроскопии свидетельствует о более выраженном структурном упорядочении волокон, сформованных из льняной целлюлозы по сравнению с волокнами, полученными из Байкальской древесной целлюлозы. Механические характеристики новых волокон находятся на уровне промыиленных гидратиеллюлозных образиов, что позволяет рассматривать льняную ијеллюлозу как альтернативный источник сырья для формования гидратиеллюлозных волокон, способных играть роль прекурсоров углеродных волокон.

Ключевые слова: лен, целлюлоза, N-метилморфолин-N-оксид, волокна, прекурсоры, структура, свойства. 


\title{
NEW FLAX CELLULOSE HYDRATE CELLULOSE FIBER
}

\author{
I. Makarov, L. Golova, M. Vinogradov, Y. Egorov, V. Kulichikhin, Y. Mikhailov
}

29, Leninskiy Avenue, Moscow, 119991, Russia. A.V. Topchiev Institute of Petrochemical Synthesis.

\begin{abstract}
A method has been developed for the preparation of new hydrated cellulose fibers from solutions of flax cellulose in $N$-methylmorpholine- $N$-oxide using a solid-phase method of solvent activation of cellulose. The solubility of flax pulp in this solvent was studied, a comparative analysis of the rheological behavior of flax and wood pulp solutions was carried out, and the optimal temperature and concentration conditions for the production of hydrated cellulose fibers were determined. The study of the structure by X-ray diffraction and IR-Fourier spectroscopy indicates a more pronounced structural ordering of fibers formed from flax cellulose compared with fibers obtained from Baikal wood pulp. The mechanical characteristics of the new fibers are at the level of industrial hydrated cellulose samples, which makes it possible to consider flax cellulose as an alternative source of raw materials for forming hydrated cellulose fibers that can play the role of carbon fiber precursors.
\end{abstract}

Keywords: flax, cellulose, N-methylmorpholine-N-oxide, fibers, precursors, structure, properties.

\section{Введение}

Основными источниками целлюлозы, используемой в России, являются древесина и хлопок, который на 100 \% является импортируемым сырьем [1]. К сожалению, климатические условия России полностью исключают возможность получения хлопка в больших объемах. При этом мировой спрос на данный продукт постоянно растет, а основным поставщикам не всегда удается даже сохранить объемы выпуска хлопка на постоянном уровне и его качество [2]. Что касается древесной целлюлозы, пригодной для получения волокон, то и здесь закрытие единственного производства с содержанием $\alpha$ - целлюлозы не менее 94 \% - Байкальского ЦБК послужило причиной полной зависимости от импорта.

Содержание целлюлозы в хлопке достигает 95 \% [3], выход целлюлозы из древесины не превышает $50 \%[4,5]$. При этом период созревания хлопка в среднем составляет 5,5-6,5 месяцев, а объем урожая варьируется от 2 до 4 тонн с гектара. В случае древесины продуктивность напрямую зависит от географического положения произрастания, а именно эвкалиптовые плантации Бразилии производят от 40 до 60 кубометров с гектара в год, в Новой Зеландии 30, продуктивность лесов России - около 1,5 кубометров с гектара в год [6].

Наряду с основными, вышерассмотренными источниками целлюлозы, в мире получают до 12 \% целлюлозы в год из однолетних растений [7]. К ним, прежде всего, относят и некоторые виды традиционного источника высококлассной целлюлозы - хлопчатника $[8,9]$. Другим однолетним растением с содер- жанием целлюлозы до 87 \% [10-12] является лен. Период продуктивности (созревания) льна составляет от 77 до 100 дней $[13,14]$. В мире один гектар позволяет собрать 1,5-1,6 тонны льняных волокон, в России 0,5-1,3 т/га [15]. Для достижения высокой урожайности льна-долгунца в льняном севообороте целесообразно использование органоминеральной системы удобрения с насыщенностью 202,5 кг д. в./га, что обеспечивает урожайность льноволокна 19,5 ц/га [16]. При глубокой переработке льноволокна в целлюлозу (после механической и химической очистки) «выход» конечного продукта не превышает 60 \% [17]. Среди многолетних растений семейства злаковых необходимо отметить мискантус [18], который, возможно культивировать в отечественных климатических условиях, включая солонцовые почвы. Селекционные сорта мискантуса позволяют получать до 4 тонн целлюлозы с гектара. Содержание целлюлозы в мискантусе доходит до 48 \% при выходе продукта $42 \%$, а лигнина до $22 \%$, содержание $\alpha$-фракции не превышает 90 \% [19]. К сожалению, на сегодня в России, посевные площади мискантуса оцениваются всего в несколько десятков гектар, что накладывает ограничения на объемы потенциально производимой целлюлозы.

Таким образом, один гектар леса в России позволяет получить не более 400 кг древесной целлюлозы в год, а равноценная посевная площадь льна до 1,3 тонн целлюлозы за сезон. К мировым лидерам по объемам посевных площадей льна относятся Канада, Россия, США, Индия и Китай [20, 21]. Посевные площади льна-долгунца в 2019 году, по статистическим данным, в хозяйствах всех категорий находились на уровне 50,6 тыс. га. Для 
сравнения, в Белоруссии за это же период было задействовано 16,6 тыс. га.

Еще одной важной проблемой в процессе получения целлюлозы является содержание лигнина в исходном сырье, который, как известно, плохо утилизируется. В зависимости от типа древесины содержание лигнина в ней доходит до 40 \% [22]. В льняных волокнах содержание лигнина варьируются от 1 до $5 \%$, в костре (одеревеневших частях стеблей) не превышает $32 \%$ [23]. Представленные выше данные позволяют говорить о преимуществах использования льна для производства целлюлозы с пониженным выделением сложно перерабатываемого лигнина в окружающую среду.

Возникает вопрос: возможно ли получать льняную целлюлозу с высоким содержанием альфа-фракции и использовать ее для формования таких высокотехнологичных материалов, как кордная нить или прекурсоры углеродных волокон? В этом отношении особый интерес представляют способы повышения содержания $\alpha$-целлюлозы в целлюлозе, полученной из льняного волокна. Этой проблеме посвящен ряд исследований.

Так, в работе $[1,24]$ использовали азотнокислый способ обработки льна-межеумка, без разделения на волокно и костру, суть которого состоит в обработке сырья разбавленным раствором азотной кислоты при атмосферном давлении с последующей обработкой пульпы разбавленным раствором гидроксида натрия. По утверждению авторов, этот способ позволяет получать целлюлозу с содержанием $\alpha$-фракции $84,63 \%$ и степенью полимеризации (СП) $\sim 500$. Повышение содержания $\alpha$-фракции в льняной целлюлозе пытались добиться с помощью ее обработки раствором гидроксида натрия и системы гидроксид натрия/пероксид водорода [25]. Этот подход выявил преимущества второй системы, с применением которой удалось увеличить содержание $\alpha$-целлюлозы с исходных $52 \%$ до $75 \%$.

Использование пероксида водорода, в двухстадийном способе получения льняной целлюлозы, где на первой стадии производится делигнификация (выход продукта составляет $72 \%$, а массовое содержание альфа-целлюлозы до 83,0 \% масс.) раствором уксусной кислоты в присутствии серной кислоты, а далее проходит дополнительное облагораживание полученного продукта щелочью, что позволяет достичь содержания $\alpha$-целлюлозы $97,5 \%$ масс. и выхода продукта $56 \%$ [26].

Исключение из процесса обработки льняного сырья кислых растворов приводит к улучшению экологических показателей. Для этого авторы работы [27] предлагают использовать короткое льняное волокно, делигнификация которого проводится с использованием щелочного раствора и поверх- ностно активных веществ. Процесс окислительной варки проводится при температуре $100{ }^{\circ} \mathrm{C}$ с последующей промывкой водой в несколько стадий с постепенным снижением температуры. Массовая доля $\alpha$-целлюлозы в получаемом продукте составляет $98,5 \%$, а его СП > 1100. Очевидно, что такие высокие значения $\alpha$-фракции и степени полимеризации делают невозможным ее растворение в традиционных апротонных органических растворителях [28], хотя даже и при более низких значениях этих показателей целлюлоза нерастворима в ряде органических растворителей.

Среди основных промышленных способов получения прядильных растворов и формовочных изделий из древесной целлюлозы являются вискозный и ММО-процесс $[29,30]$. Использование в вискозном процессе многостадийной обработки целлюлозы при наличии агрессивных и токсичных реагентов [31] приводит к деструкции целлюлозы [32] и делают его экологически неприемлемым.

Альтернативным вискозному способу является ММО-процесс, в котором используется прямой растворитель древесной целлюлозы $\mathrm{N}$-метилморфолин$\mathrm{N}$-оксид (NMMO), и этот процесс был промышленно реализован [33, 34]. Растворяющая способность этого растворителя лимитируется содержанием в нем воды. Как показано в работе [35], максимальной активности растворителя по отношению к целлюлозе и возможности получения высококонцентрированных растворов (до $50 \%$ удается достичь при содержании воды в растворителе до $3 \%$ $\left(\mathrm{T}_{\text {пл. }}=150-170{ }^{\circ} \mathrm{C}\right)$. Для получения прядильных растворов, содержащих до 18 \% целлюлозы, используется NMMO с содержанием воды 8-10 \% и температурой плавления $120-140{ }^{\circ} \mathrm{C}$.

Однако тот факт, что растворитель является твердым при обычных условиях, потребовало неординарных решений для получения прядильных растворов. В нашей группе был разработан т.н. твердофазный способ растворения порошковой целлюлозы в кристаллогидрате $\mathrm{NMMO}$, состоящий в механической обработке твердофазной смеси в условиях сдвигового деформирования. Такая обработка позволила получать твердофазные предрастворы, которые при нагревании переходят в текучее состояние и дополнительно гомогенизируются при течении через капилляр [36]. В этой связи, большой научный и практический интерес представляет исследование возможности твердофазного растворения льняной целлюлозы в NMMO с целью использования полученных растворов в качестве прядильных при получении гидратцеллюлозной технической нити. Это принципиально новое направление в расширении способов переработки льняной целлюлозы, не имеющее, 
как известно авторам из доступных источников, аналогов в литературе.

Исследование растворимости льняной целлюлозы в NMMO, получение гомогенных растворов и изучение их реологического поведения, выбор условий формования волокон из полученных растворов, а также исследование структуры, морфологии, механических и термических свойств, полученных ГЦ волокон является целью данной работы.

\section{Экспериментальная часть}

В работе использовали порошковую льняную целлюлозу (ООО «АПК Вологодчина», Россия) со степенью полимеризации 720, содержанием влаги $\sim 8 \%$, массовым содержанием в сухом остатке альфа-целлюлозы $~ 92 \%$, размером частиц $<250$ мкм и сульфатную целлюлозу (Байкальский целлюлозно-бумажный комбинат, Россия) (СП = 600, содержание влаги $\sim 8 \%$, содержание $\alpha$-целлюлозы $\sim 94$ \%). Целлюлозу растворяли в N-метилморфолин$\mathrm{N}$-оксиде (Demochem, Китай) с содержанием воды 8-10\% ( $\left.\mathrm{T}_{\text {пл. }} \sim 120-140{ }^{\circ} \mathrm{C}\right)$. Термоокислительную деструкцию подавляли введением в систему 0,5 \% пропилгаллата (Sigma-Aldrich, США).

Растворы целлюлозы в NMMO с содержанием полимера от 10 до 18 \% готовили по методике твердофазного растворения, описанной в работе [37]. Формовочные растворы получали нагреванием твердофазных прекурсоров до точки плавления растворителя и дополнительно гомогенизировали их пропусканием через капилляр с диаметром (d) 0,5 мм и длиной (1) 5 мм $(1 / \mathrm{d}=10)$ в вискозиметре Rheoscope 1000 (CEAST, Италия) при температуpe $120-135{ }^{\circ} \mathrm{C}$. Оценка качества полученного раствора осуществлялась методом поляризационной микроскопии (микроскоп «Boetius», VEB Kombinat Nadema, бывшая ГДР).

Вязкость растворов с содержанием льняной целлюлозы от 10 до $18 \%$ оценивали при $120{ }^{\circ} \mathrm{C}$ на ротационном реометре Physica MCR 301 (Anton Paar, Австрия), снабженного рабочим узлом конусплоскость (диаметр 25 мм) в условиях непрерывного режима деформирования в диапазоне скоростей сдвига от $10^{-3}$ до $10^{3} \mathrm{c}^{-1}$.

Формование (наработку) укрупненных партий льняных волокон проводили на лабораторной установке сухо-мокрого формования (рис. 1), созданной на базе одношнекового экструдера, и оснащенной осадительной ванной, стадией отмывки формующейся нити, состоящей из трех пар промывных цилиндров с синхронным вращением, сушки получаемого волокна и устройством приемки нити (нитераскладчиком).

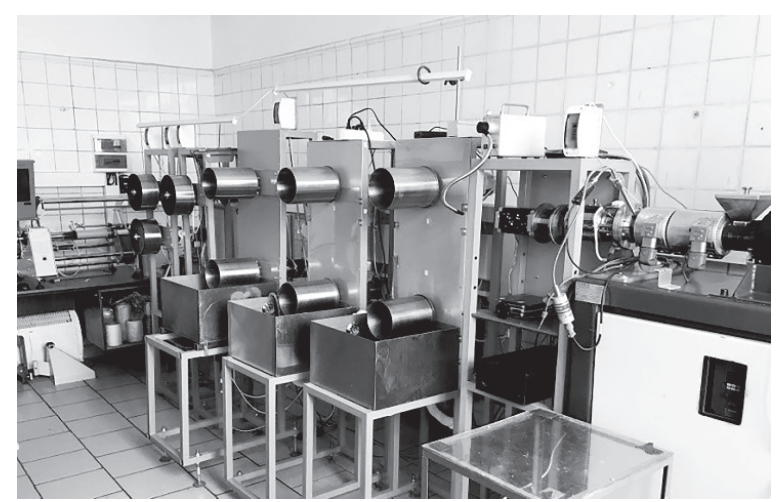
Рис. 1. Лабораторная установка сухо-мокрого
формования

Температура прядильного комплекта, состоящего из прядильного насоса и фильерного блока, поддерживалась в диапазоне $120-125^{\circ} \mathrm{C}$. Для формования волокон использовали фильеру с числом отверстий 17 диаметром 250 мкм. Величина воздушного зазора составляла 8-10 см, кратность вытяжки варьировали от 15,4 до 22 . Температура воды в первых двух промывных контурах была в пределах $15-18{ }^{\circ} \mathrm{C}$, третьего $-45^{\circ} \mathrm{C}$. Сушку волокон осуществляли при температуре $85-90{ }^{\circ} \mathrm{C}$ до равновесного содержания влаги.

Механические свойства волокон определяли на разрывной машине Instron 1122 при скорости растяжения 10 мм/мин при базе 10 мм согласно ГОСТ 10213.4-2002.

Структуру волокон исследовали методами РСА и ИК-Фурье спектроскопии. Для рентгеновской дифрактометрии использовали установку Rigaku Rotaflex RU-200, оснащенную вращающимся медным анодом (линейный фокус 0,5·10 мм, режим работы источника 50 кВ - 100 мА, длина волны характеристического $\mathrm{CuK \alpha} \alpha$-излучения $\lambda=1,542 \AA$, вторичный графитовый монохроматор), горизонтальным гониометром D-Max/B и сцинтилляционным детектором. Рентгеновскую съемку производили в геометрии на «прохождение» по схеме Брэгга-Брентано в режиме непрерывного $\theta-2 \theta$ сканирования в угловом диапазоне $5-40^{\circ}$, скоростью $2 \%$ мин и шагом сканирования $0,04^{\circ}$. Измерения проводили при комнатной температуре. В качестве объектов использовали пучки из 100-150 моноволокон, которые закрепляли на плоской квадратной алюминиевой рамке перпендикулярно плоскости вращения детектора (экваториальное положение).

ИК спектры волокон регистрировали на ИК-микроскопе HYPERION-2000, сопряженном с ИК-Фурье спектрометром IFS-66 v/s Bruker (кристалл - Ge, скан. 50, разрешение $2 \mathrm{~cm}^{-1}$, диапазон 4000-600 $\left.\mathrm{cm}^{-1}\right)$. 
Морфологию поверхности и поперечных сколов волокон исследовали методом низковольтной растровой электронной микроскопии (РЭМ) на микроскопе FEI Scios (CША) при ускоряющем напряжении менее 1 кВ в режиме вторичных электронов.

Термическое поведение волокон исследовали на приборе DSC 823e Mettler Toledo (Швейцария). Измерения проводили в алюминиевых тиглях объемом 40 мкл без перфорации в диапазоне температур 50-100 ${ }^{\circ} \mathrm{C}$ при скорости нагрева 10 К/мин. Расход инертного газа (аргон) составлял 70 мл/мин.

\section{Результаты и их обсуждение}

Проведены ИК-спектроскопические исследования структурных особенностей льняной целлюлозы (ООО «АПК Вологодчина») и древесной целлюлозы Байкальского ЦБК. При использовании методов ИК спектроскопии для оценки степени упорядоченности полимерных цепей целлюлозы в качестве полос внутреннего стандарта используют полосы $2900 \mathrm{~cm}^{-1}\left(v_{\mathrm{CH}}\right)$ и $1370 \mathrm{~cm}^{-1}$ (деформационное колебание сложной формы, включающее деформацию - $\mathrm{OH},-\mathrm{CH}$ и $-\mathrm{CH}_{2}$ групп). Наиболее чувствительной к степени кристалличности целлюлозы оказывается относительная интенсивность полос 1370/2900. Индексом кристалличности по О'Коннору считают [12] относительную интенсивность полос 1430/900 которая отражает боковую упорядоченность макромолекул целлюлозы, т.к. полоса $1430 \mathrm{~cm}^{-1}$ принадлежит в основном деформационным колебаниям группы -ОН.

В таблице 1 сведены относительные интенсивности полос, чувствительных к упорядочению цепей целлюлозы к полосам $2900 \mathrm{~cm}^{-1}\left(v_{\mathrm{CH}}\right)$. Первое, что обращает на себя внимание, это кардинальное отличие структуры льняной целлюлозы от структуры древесной целлюлозы. Оценка индекса кристалличности по О'Коннору и по относительной интенсивности полос 1370/2900 свидетельствует о том, что в льняной целлюлозе по сравнению с древесной более выражена как внутрицепная, так и межцепная структурная упорядоченность. При этом аморфной фазы (строки 6-8) в льняной целлюлозе значительно меньше, чем в древесной целлюлозе, для которой значения отношений интенсивности полос 1030/2900 = 3,62 и 1152/2900 = 1,04 имеют высокие значения.

Более высокая степень упорядочения и кристалличности льняной целлюлозы привносит определенные сложности в процесс ее растворения в NMMO. Так, если в используемом гидрате NMMO (содержание воды 8-10\%) растворяется до $25 \%$ древесной целлюлозы, то для льняной целлюлозы предельная растворимость с получением кондиционных прядильных растворов не превышает $18 \%$. При этом следует иметь в виду, что увеличение концентрации льняной целлюлозы в растворе с 10 до 18 \% приводит к необходимости повышения температуры растворения от 120 до $135-140{ }^{\circ} \mathrm{C}$.

В ходе работы были получены растворы льняной целлюлозы в NMMO с концентрацией $10-18$ \% и исследованы их реологические свойства. Кривые течения растворов льняной и древесной целлюлоз в диапазоне концентраций 10-18 \% представлены на рис. 2.

Как видно из представленных рис. 2 зависимостей, вязкость $18 \%$-ного раствора льняной целлюлозы на порядок выше вязкости эквиконцентрированного раствора древесной целлюлозы. Другими словами, для реализации той же вязкости, которая характерна $18 \%$-ному раствору древесной

\section{Оценка относительных интенсивностей отдельных полос в ИК спектрах порошков льняной и древесной целлюлозы и ГЦ нитей, полученных на их основе}

\begin{tabular}{cccccc}
\hline \multirow{2}{*}{$\begin{array}{c}\text { Отонсительные } \\
\text { интенсивности }\end{array}$} & $\begin{array}{c}\text { Целлюлоза } \\
\text { древесная } \\
\text { (порошок) }\end{array}$ & $\begin{array}{c}\text { Целлюлоза } \\
\text { льняная } \\
\text { (порошок) }\end{array}$ & $\begin{array}{c}\text { ГЦ нить из } \\
\text { древесной } \\
\text { целлюлозы }\end{array}$ & $\begin{array}{c}\text { ГЦ нить } \\
\text { из льняной } \\
\text { целлюлозы }\end{array}$ \\
\hline 1 & $\begin{array}{c}\mathrm{D}_{1430} / \mathrm{D}_{900} \\
\text { (индекс крист. по О'Коннору }\end{array}$ & 1,09 & 1,97 & 1,27 & 1,77 \\
2 & $\mathrm{D}_{1370} / \mathrm{D}_{2900}$ & 0,76 & 0,91 & 0,65 & 0,88 \\
3 & $\mathrm{D}_{1650} / \mathrm{D}_{2900}$ & 0,34 & 0,40 & 0,20 & 0,57 \\
4 & $\mathrm{D}_{1430} / \mathrm{D}_{2900}$ & 0,65 & 0,75 & 0,33 & 0,73 \\
5 & $\mathrm{D}_{1321} / \mathrm{D}_{2900}$ & 0,74 & 0,83 & 0,64 & 0,74 \\
6 & $\mathrm{D}_{1152} / \mathrm{D}_{2900}$ & 1,04 & 0,69 & 0,47 & 0,64 \\
7 & $\mathrm{D}_{1030} / \mathrm{D}_{2900}$ & 3,62 & 2,86 & 2,69 & 2,88 \\
8 & $\mathrm{D}_{900} / \mathrm{D}_{2900}$ & 0,63 & 0,37 & 0,33 & 0,42 \\
\hline
\end{tabular}




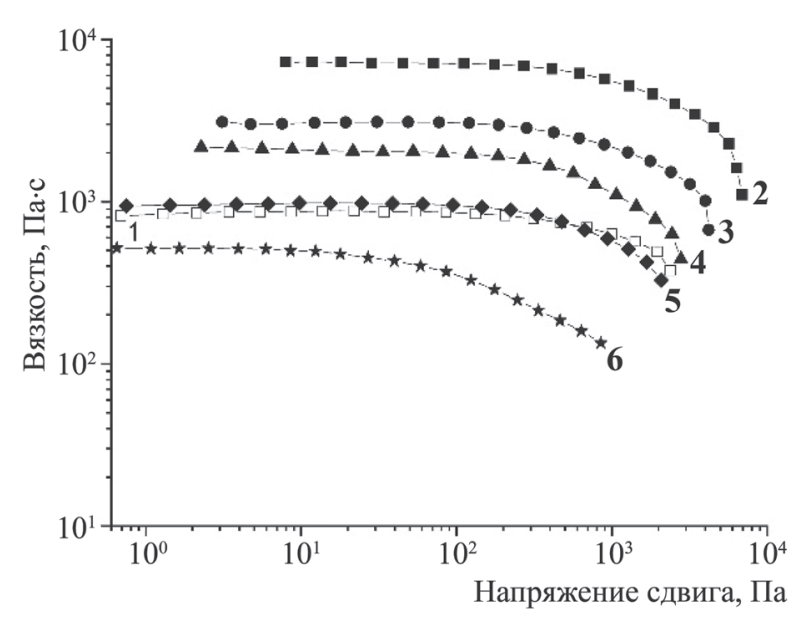

Рис. 2. Зависимость вязкости от напряжения сдвига растворов древесной целлюлозы с концентрацией 18 \% (1) и льняной целлюлозы с концентрацией $18(2), 16(3), 14(4), 12$ (5) и $10 \%$ (6)

целлюлозы, необходимо снизить содержание льняной целлюлозы в растворе до 12 \%. При этом характер кривых течения растворов льняной и древесной целлюлозы полностью идентичен практически при всех концентрациях. В области низких скоростей и напряжений сдвига исследуемые системы проявляют ньютоновский характер течения. С увеличением напряжения сдвига до $10^{2,5}$ Па наблюдается снижение вязкости.

При увеличении содержания льняной целлюлозы вязкость возрастает линейно, как это видно из представленной на рис. 3 концентрационной зависимости вязкости.

Концентрационная зависимость, представленная на рис. 3, описывается степенной зависимо-

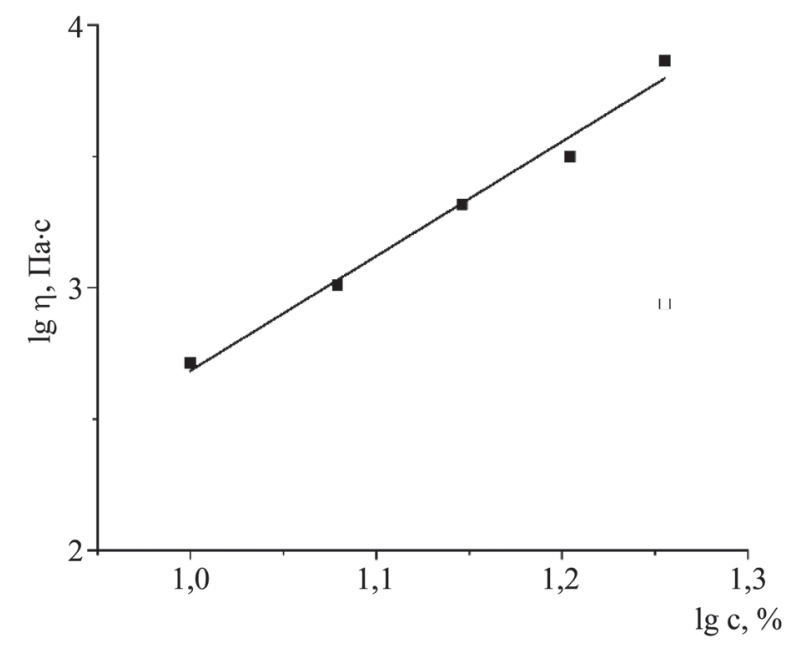

Рис. 3. Концентрационная зависимость вязкости растворов льняной целлюлозы в NMMO

Открытым символом показана вязкость $18 \%$-ного раствора древесной целлюлозы стью: $\mathrm{h} \sim \mathrm{c}^{\mathrm{n}}$. Для исследуемых растворов льняной целлюлозы в NMMO показатель степени $\mathrm{n}=6,5$, что является типичной величиной для растворов полимеров.

Формуемость целлюлозных растворов оценивали на капиллярном вискозиметре, снабженном после выхода струи раствора из фильеры/капилляра водной осадительной ванной и приемным роликом. Для улучшения прядомости растворов с концентрацией более $14 \%$ температуру рабочего узла увеличивали со 122-125 до $130-135^{\circ} \mathrm{C}$.

Данные реологических исследований и определенные температурно-концентрационные параметры формования на капиллярном вискозиметре позволили выбрать температурно-концентрационный диапазон для наработки укрупненных партий льняных волокон на лабораторном стенде сухо-мокрого формования.

Полученные гидратцеллюлозные льняные волокна имеют красивый серебристый цвет, присущий натуральным льняным волокнам (рис. 4). Очевидно, что структурные особенности нативной льняной целлюлозы могут влиять на структуру и морфологию полученных волокон, которые, в свою очередь, определяют их механические и термические свойства. Для выявления этих закономерностей была исследована структура льняных ГЦ волокон, полученных на стенде сухо-мокрого формования, методами РСА и ИК-Фурье спектроскопии.

Полученные волокна (рис. 5) характеризуются традиционными для целлюлозы II рефлексами в области $2 \mathrm{q} \sim 12,3^{\circ}, \sim 20,5^{\circ}$ и $\sim 21,9^{\circ}$, что полностью совпадает с соответствующими рефлексами волокон из древесной целлюлозы [38, 39].

Наряду со спектральными оценками степени упорядоченности образцов различной целлюло-

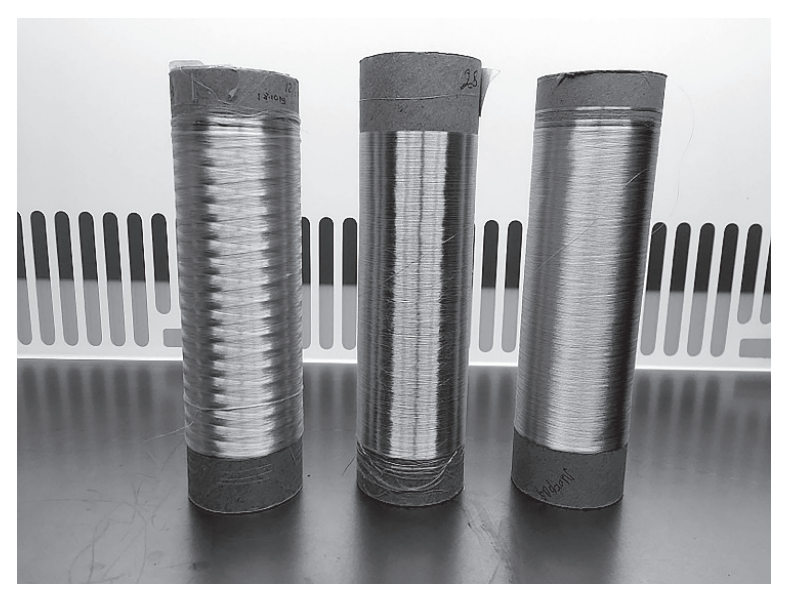

Рис. 4. Фотографии волокон, полученных из 12 \%-ных растворов льняной целлюлозы в NММО 


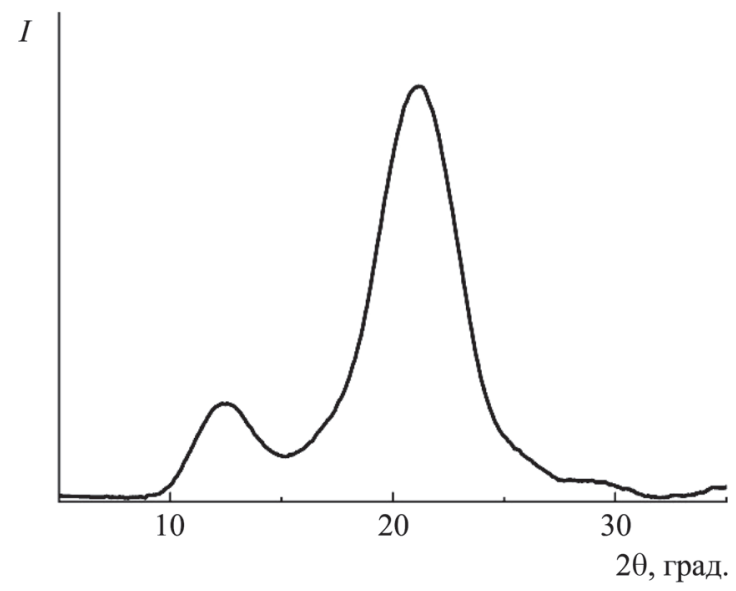

Рис. 5. Экваториальная дифрактограмма волокон, полученных из 12 \%-ных растворов льняной целлюлозы (съемка на прохождение)

зы приведены также спектральные исследования сформованных ГЦ волокон, которые, как видно из таблицы 1 , свидетельствуют об определяющем влиянии структуры исходных целлюлоз на характер структурных перестроек в процессе переработки в волокна.

Так, в льняных ГЦ волокнах наблюдается незначительная потеря степени упорядочения и кристалличности по сравнению с нативной льняной целлюлозой. При этом количество аморфных участков в цепях и их размеры практически не меняются. В отличие от льняной целлюлозы, макромолекулы древесной целлюлозы, имеющие меньшее межцепное упорядочение, в процессе ориентационной вытяжки дополнительно организуются (индекс кристалличности по О’Коннору возрастает от 1,09 до 1,27$)$, образуя более протяженные кристалличе-

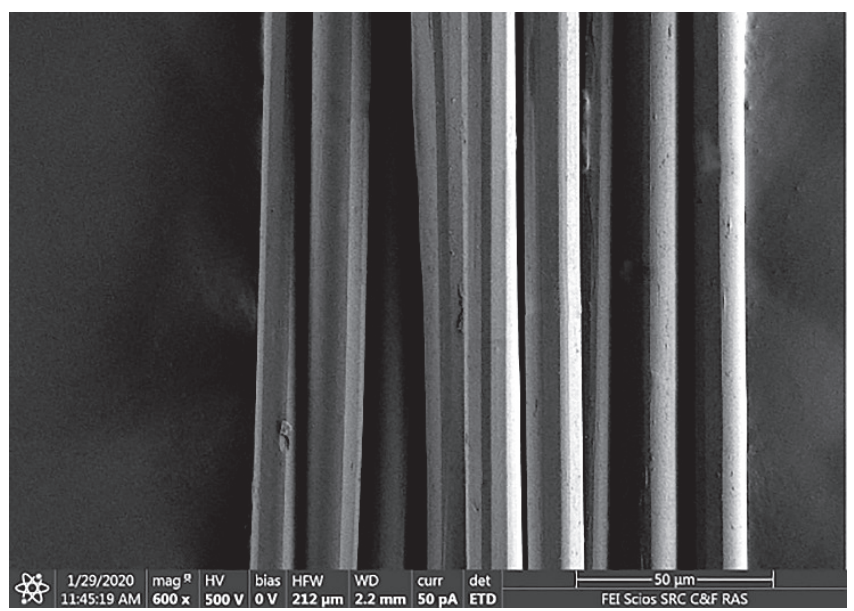

a ские участки, вытянутые вдоль оси волокна по сравнению с исходной древесной целлюлозой. Количество аморфной фазы в сформованных ГЦ нитях при этом существенно уменьшается, о чем свидетельствуют уменьшенные практически вдвое значения отношений интенсивности полос 1030/2900 и 1152/2900, что дает возможность предположить о реализации в аморфных участках макромолекул древесной целлюлозы определенного упорядочения. Суммируя полученные данные можно заключить, что структура льняных волокон характеризуется высокоупорядоченными участками кристаллической фазы, разделенными аморфными последовательностями с невысокой степенью упорядочения, присущей исходной льняной целлюлозе.

Изучение волокон с помощью СЭМ позволило выявить их морфологическое строение. Так, если натуральный длинноволокнистый лен имеет гладкую поверхность волоконец, а в поперечном срезе форму многоугольника со свободным пространством в середине [40], то, полученное ГЦ льняное волокно, как видно из рис.6, имеет морфологию, близкую к морфологии волокон из древесной целлюлозы.

Подобно ГЦ древесным нитям, льняная нить состоит из моноволокон с гладкой поверхностью и средним диаметром 14 мкм. Поперечное сечение филаментов круглое, а на сколе видна плотная микрофибриллярная текстура.

Как видно из таблицы 2 , ГЦ волокна из льняной целлюлозы, полученные по схеме, аналогичной условиям формования волокон из древесной целлюлозы, характеризуются высокими прочностными и деформационными свойствами, практически не уступающими волокнам из древесной целлюлозы.

Обращает на себя внимание более высокие значения относительного удлинения при разры-

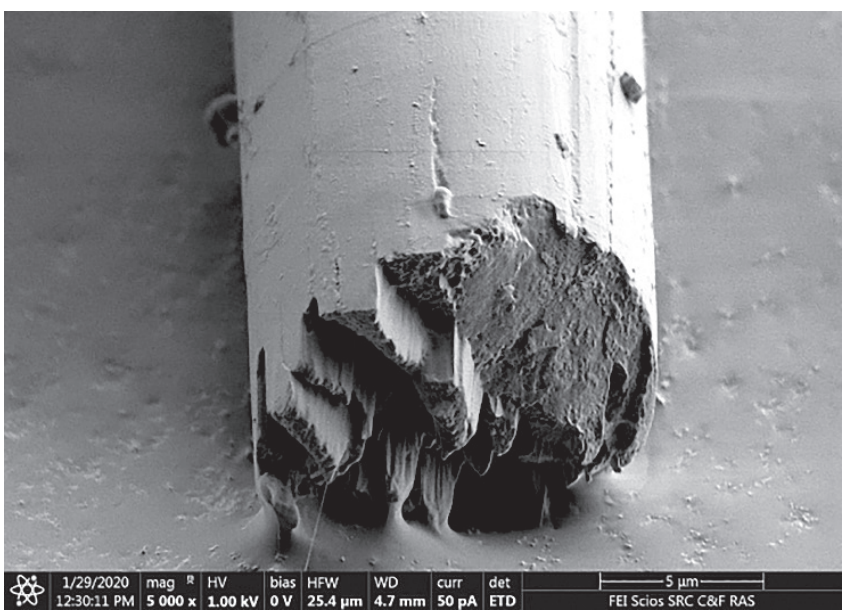

б

Рис. 6. Микрофотографии волокон, сформованных из льняной целлюлозы, поверхность (а) и поперечный скол (б) 
Таблииа 2

Механические свойства волокон, полученных из льняной и древесной целлюлозы

\begin{tabular}{ccccc}
\hline $\mathbf{C}_{\text {р-ра }}, \%$ & d, мкм & $\delta$, Мпа & Е, ГПа & $\varepsilon, \%$ \\
\hline 12 & $12-17$ & $540-680$ & $12-15$ & $9-12$ \\
14 & $12-23$ & $410-610$ & $9-12$ & $6-10$ \\
16 (древ.) & $16-20$ & $610-730$ & $14-20$ & $6-9$ \\
\hline
\end{tabular}

ве льняных волокон. Это качество является существенным преимуществом льняных гидратцеллюлозных волокон, открывающим широкие возможности их текстильной переработки по сравнению как с природными льняными волокнами, имеющими удлинение не более 2,5 \% [41], так и с волокнами на основе древесной целлюлозы.

Новые ГЦ льняные волокна, ввиду выявленных структурно-механических особенностей, представляют несомненный интерес для изучения возможности их использования их в качестве прекурсоров углеродных волокон. В этой связи были исследованы термические свойства таких волокон. Данные ТГА и ДСК для волокон, полученных из 12 \%-ных растворов льняной целлюлозы в NMMO, представлены на рис. 7.

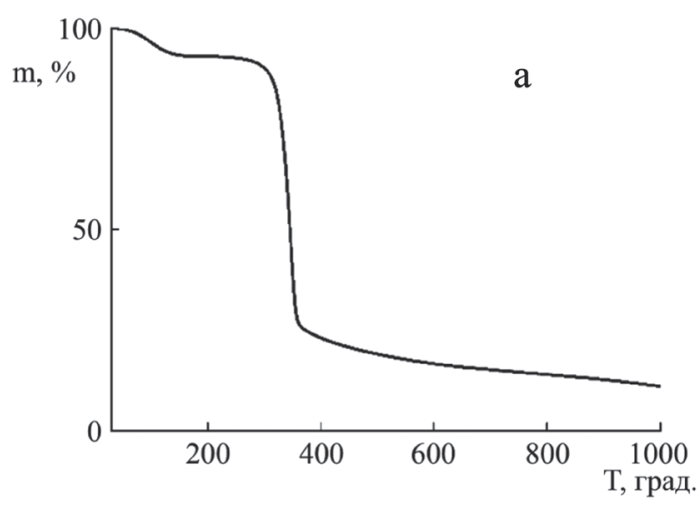

На ДСК термограмме (рис. 7б) ГЦ льняной целлюлозы после удаления влаги присутствует небольшой по величине, но протяженный экзотермический пик в области 279-317 ${ }^{\circ} \mathrm{C}$ и эндотермический пик с максимумом при $347^{\circ} \mathrm{C}$. По положению максимумов пиков и значениям тепловых эффектов полученная термограмма незначительно отличается от термограммы ГЦ волокон из древесной целлюлозы. По всей видимости, наблюдаемые экзотермические эффекты свидетельствуют о предпочтительном протекании в исследуемых образцах реакций термодегидратации, сопровождающихся структурными перестройками глюкопиранозных колец целлюлозы в сопряженные циклические структуры. Эндопик, по всей видимости, соответствует деполимеризационным процессам.

Проведенные предварительные исследования по получению углеродных волокон из льняных прекурсоров позволили получить на их основе углеродные волокна, прочность которых находятся уровне 1 ГПа.

Таким образом, в данной работе фактически впервые получены ГЦ льняные волокна на основе быстро воспроизводимой в природе льняной целлюлозы, механические свойства которых открывают широкие возможности получения из них тек-

Рис. 7. ТГА (а) и ДСК (б) данные для волокон, сформованных из 12 \%-ных растворов льняной целлюлозы в NMМO Атмосфера: аргон $10 \mathrm{~cm}^{3} /$ мин. Линейный нагрев со скоростью $10 \mathrm{~K} / \mathrm{мин}$

На кривой ТГА (рис. 7а) определяются три участка потери массы образца при нагреве до $1000{ }^{\circ} \mathrm{C}$ [42], которые соответствуют удалению адсорбированной воды, пиролизу целлюлозы и высокотемпературный участок, начиная с $380^{\circ} \mathrm{C}$, где наблюдается снижение массы в результате карбонизации. Доля углеродного остатка при $1000{ }^{\circ} \mathrm{C}$ составляет 10,2 \%, что, в общем случае, характерно для целлюлозных прекурсоров, не подвергавшихся дополнительной обработке катализаторами пиролиза и антипиренами [43]. стильных материалов, волокон специального назначения и прекурсоров углеродных волокон.

Авторы работь выражают благодарность Л.К. Кузнецовой, Г.Н. Бондаренко, И.С. Левину, Г.А. Шандрюку, Н.А. Архаровой, за помощь в наработке образов и исследование структурных особенностей волокон методами ИК-спектроскопии, РСА, ТГА, ДСК и СЭМ.

Работа выполнена при финансовой поддержке РНФ грант (№17-79-30108). 


\section{Лuтература}

1. Гисматулина Ю.А. Ползуновский вестник. №3. 2014. C. 160-163.

2. Морыганов А.П., Захаров А.Г., Живетин В.В. Рос. хим. ж. (Ж. Рос. хим. об-ва им. Д.И. Менделеева). 2002. T. XLVI. № 1. C. 58-65.

3. Christie R.M. Colour Chemistry. Royal Society of Chemistry. 2001. P. 205.

4. Kudela J., Kurjatko S., Jozel Kudela. Wood Structure and Properties '02. Arbora Publishers. 2002. P. 221.

5. Zhang Q., Wei F. Advanced Hierarchical Nanostructured Materials. John Wiley \& Sons. 2014. P. 512.

6. Аким Э.Л. Био-рефайнинг древесины. Сборник тезисов конференции «Международное сотрудничество в сфере биоэнергетики». 22-23 октября 2013, Москва. https://www.unece.org/fileadmin/DAM/timber/meetings/20130522/presentations/06-Biotechnology_Platform_Eduard_Akim_Rissian.pdf

7. Bowyer J.L., Stockmann V.E. Forest Product Journal. 2001. V. 49 № 193. P. 10-21.

8. Smith C.W., Cothren J.T. Cotton: Origin, History, Technology, and Production. John Wiley \& Sons. 1999. P. 872.

9. Cotton. United States. Congress. House. Committee on Agriculture. U.S. Government Printing Office. 1945. P. 850.

10. Nag S., Mitra J., Karmakar P.G.. International Journal of Agriculture, Environment and Biotechnology. 2015. V. 8. № 4. P. 805-817. DOI: $10.5958 / 2230-$ 732X.2015.00089.3

11. Wiener J., Kovacic V., Dejlova P. Differences between flax and hemp. AUTEX Research Journal. V. 3. № 2. 2003. P. 58-63.

12. Байклз Н., Сегал Л. Целлюлоза и её производные. Том 1. Под редакцией 3.А. Роговина - М.: Мир, 1974. - 499 c.

13. Goudenhooft C., Bourmaud A., Baley C. Flax (Linum usitatissimum L.) Fibers for Composite Reinforcement: Exploring the Link Between Plant Growth, Cell Walls Development, and Fiber Properties. Front. Plant Sci., 2019. V. 10. P. 411. https://doi.org/10.3389/ fpls.2019.00411

14. Davies R.S., Guild P. Flax, from Seed to Linen Yarn. The journal for weavers, spinners and dyers.https:// journalwsd.org.uk/article/flax-from-seed-to-linen-yarn.

15. Коновалов В.В. Состояние и перспективы развития льноводства в Российской Федерации. Вестник Текстильлегпрома. Осень 2018. С. 38-39.

16. Сорокина О.Ю., Кузьменко Н.Н., Сухопалова Т.П., Ильина В.И. Достижения науки и техники АПК. 2019. Т. 33. № 8. С. 18-23. DOI: 10.24411/0235-24512019-10804.

17. Морьганов А.П. Отечественное растительное волокнистое сырье: перспективы производства и переработки. Вестник Текстильлегпрома. Осень. 2018. С. 40-42.

18. Будаева В.В., Митрофанов Р.Ю., Золотухин В.Н., Архипова О.С. Ползуновский вестник. 2010. №3. C. 240-245.

19. Гисматулина Ю.А. Фундаментальные исследования. 2014. Т. 6. № 6. С. 1195-1198.
20. Muir A.D., Westcott N.D. Flax: The genus Linum. CRC Press. 2003. P. 320.

21. McKeon T., Hayes D.G., Hildebrand D., Weselake R. Industrial Oil Crops. Elsevier. 2016. P. 474.

22. Sjostrom E. Wood Chemistry: Fundamentals and Applications. Elsevier. 2013. P. 293.

23. Бочек А.М., Шевчук И.Л., Лаврентьев В.Н. Журнал прикладной химии. 2003. Т. 76. № 10. С. 1725-1728.

24. Будаева В.В., Гисматулина Ю.А., Золотухин В.Н., Роговой М.С., Мельников А.В. Способ получения целлюлозы из льна-межеумка для бумажной промышленности. Патент РФ 2566275. 2015.

25. Kopania E., Wietecha J., Ciechańska D. Fibres \& Textiles in Eastern Europe. 2012. 20. 6B (96). P. 167-172.

26. Левданский В.А., Левданский А.В., Кузнеиов Б.Н. Journal of Siberian Federal University. Chemistry. 2014. T. 1. C. 63-70.

27. Егоров Д.А., Луканин Е.А. Целлюлозный продукт с содержанием альфа-целлюлозы 98,5 \% и выше и промышленный способ его получения. Патент РФ 2017141513. 2019.

28. Makarov I.S., Golova L.K., Vinogradov M.I., Levin I.S., Gromovykh T.I., Arkharova N.A., Kulichikhin V.G. Fibre Chemistry. 2019. V. 51. №3. P. 175-181.

29. Perepelkin K.E. 2008. V. 40. № 1. P. 10.

30. Golova L.K., Makarov I.S., Matukhina E.V., Kuptsov S.A., Shambilova G.K., Kulichikhin V.G. Polymer Science. A. 2008. V. 50. №6. P. 665.

31. Golova L.K.. Ross. Khim. Zh. 2002. V. 46. № 1. P. 49.

32. Strunk P., Lindgren A., Eliasson B., Agnemo R. Cellulose Chem. Technol. 2012. V. 46 (9-10). P. 559-569.

33. Johnson D.L. US Patent 3447939. 1969.

34. Golova L.K. Fibre Chemistry. 1996. V. 28. № 1. P. 5-16. DOI: 10.1007/BF01130691.

35. Golova L.K., Borodina O.E., Kuznetsova L.K., Lyubova T.A., Krylova T.B. Fibre Chemistry. 2000. V. 32(4). P. 243-251. DOI: 10.1023/A:1004194913945.

36. Голова Л.К., Куличихин В.Г., Папков С.П. Высокомол. соед. Сер. А. 1986. Т. 27. № 9. С. 1795-1809.

37. Голова Л.К. и др. Патент РФ. 1645308. 1992.

38. Makarov I.S., Golova L.K., Kuznetsova L.K., Mironova M.V., Vinogradov M.I., Bermeshev M.V., Levin I.S., Kulichikhin V.G. Fibre Chemistry. 2019. V. 51. № 1. P. 2631. DOI: 10.1007/s10692-019-10041-4.

39. Kaplan D.L. Biopolymers from Renewable Resources. 2013. Springer Science \& Business Media. P. 420.

40. Kozlowski R.M., Mackiewicz-Talarczyk M. Handbook of Natural Fibres: Volume 1: Types, Properties and Factors Affecting Breeding and Cultivation. Woodhead Publishing, 2020. P. 838.

41. Charlet K., Jernot J.-P., Gomina M. Journal of composite materials. 2010. V. 44. №24. P. 2887-2896. DOI:10.1177/0021998310369579.

42. Makarov I.S., Golova L.K., Bondarenko G.N., Skvortsov I.Yu., Berkovich A.K., Bermeshev M.V., Mironova M.V. Fibre Chemistry. 2017. V. 49. №4. P. 231-236. DOI: 10.1007/s10692-018-9874-6.

43. Конкин A.A. Углеродные и другие жаростойкие волокнистые материалы. Москва. Химия; 1974. С. 376. 